\title{
Characterization of $\mathrm{V}_{2} \mathrm{O}_{5} / \mathrm{MoO}_{3}$ composite photocatalysts prepared via electrospinning and their photodegradation activity for dimethyl phthalate
}

\author{
Hongyuan Chuai a, Defeng Zhou b,*, Xiaofei Zhu b, Zhaohui Li b, Weiping Huang a,\# \\ ${ }^{a}$ College of Chemistry, Collaborative Innovation Center of Chemical Science and Engineering (Tianjin); Tianjin Key Laboratory of Metal and \\ Molecule-based Material Chemistry, Nankai University, Tianjin 300071, China \\ ${ }^{\mathrm{b}}$ School of Chemistry and Life Science, Changchun University of Technology, Changchun 130012, Jilin, China
}

\section{A R T I C L E I N F O}

Article history:

Received 26 August 2015

Accepted 29 October 2015

Published 20 December 2015

\section{Keywords:}

Electrospinning

Vanadium pentoxide

Molybdenum trioxide

Composites

Photodegradation activity

Dimethyl phthalate

\begin{abstract}
A B S T R A C T
Vanadium pentoxide $\left(\mathrm{V}_{2} \mathrm{O}_{5}\right)$ /molybdenum trioxide $\left(\mathrm{MoO}_{3}\right)$ composites with different molar ratios of vanadium (V) to molybdenum (Mo) were synthesized via a simple electrospinning technique. The photocatalytic activity of the composites were evaluated by their ability to photodegrade methylene blue and dimethyl phthalate (DMP) under visible-light irradiation. Compared with pure $\mathrm{V}_{2} \mathrm{O}_{5}$ and $\mathrm{MoO}_{3}$, the $\mathrm{V}_{2} \mathrm{O}_{5} / \mathrm{MoO}_{3}$ composites showed enhanced visible-light photocatalytic activity because of a $\mathrm{V} 3 d$ impurity energy level and the formation of heterostructures at the interface between $\mathrm{V}_{2} \mathrm{O}_{5}$ and $\mathrm{MoO}_{3}$. The optimal molar ratio of $\mathrm{V}$ to $\mathrm{Mo}$ in the $\mathrm{V}_{2} \mathrm{O}_{5} / \mathrm{MoO}_{3}$ composites was found to be around $1 / 2$. Furthermore, high-performance liquid chromatographic monitoring revealed that phthalic acid was the main intermediate in the photocatalytic degradation process of DMP.
\end{abstract}

(C) 2015, Dalian Institute of Chemical Physics, Chinese Academy of Sciences. Published by Elsevier B.V. All rights reserved.

\section{Introduction}

Dimethyl phthalate (DMP) is widely used as an additive in the manufacture of plastics, polyvinyl acetates and cellulosics even though it is an endocrine-disrupting chemical and has great potential to interfere with the hormonal control systems of humans. With the manufacture and use of DMP, it is inevitably discharged into the environment [1-3]. It is important to effectively remove DMP from aqueous systems to minimize its adverse effects. An attractive method to remove DMP is photocatalytic treatment using solar radiation in the presence of a photocatalyst. In this respect, a semiconductor photocatalyst that is inexpensive and stable under ambient conditions is required for use in clean technology.

In recent years, applications of semiconductors in the elimination of environmental pollutants from aquatic solutions have been attracting increasing attention because of their high physicochemical stability and photocatalytic performance $[4,5]$. Semiconductors like titanium dioxide $\left(\mathrm{TiO}_{2}\right)$ [6-9], molybdenum trioxide $\left(\mathrm{MoO}_{3}\right)$ [10-13], vanadium pentoxide $\left(\mathrm{V}_{2} \mathrm{O}_{5}\right)$ [14-16], tungsten oxide $\left(\mathrm{WO}_{3}\right)$ [17-19], cerium oxide $\left(\mathrm{CeO}_{2}\right)$ [20], zinc oxide (ZnO) [21], and cadmium sulfide (CdS) [22,23], are widely used as photocatalysts. However, a common drawback of these photocatalysts is the fast recombination of pho-

\footnotetext{
* Corresponding author. Tel: +86-431-85717276; E-mail: defengzhou65@126.com

\# Corresponding author. Tel: +86-13820096974; E-mail: hwp914@nankai.edu.cn

This work was supported by the National Natural Science Foundation of China (21373120, 21471022), the Development of Science and Technology Plan of Jilin Province, China (20101549, 20130102001JC), Program for Changjiang Scholars and Innovative Research Team in University (PCSIRT13022) of China, and the Program of Jilin Provincial Education Department $(2013130,2013146)$.

DOI: 10.1016/S1872-2067(15)61002-6 | http://www.sciencedirect.com/science/journal/18722067 | Chin. J. Catal., Vol. 36, No. 12, December 2015
} 
togenerated electron-hole pairs in them, which lowers their photocatalytic efficiency. Several methodologies have been used to decrease the recombination rate of photogenerated electron-hole pairs and to enhance the photocatalytic efficiency of semiconductor photocatalysts, such as doping with metals (gold, vanadium, tungsten, strontium) [24-27] or nonmetals (carbon, nitrogen, sulfur) [28-30], surface modification [31,32], and combination with another semiconductor [33,34]. In our previous work, we used the semiconductor compound $\mathrm{MoO}_{3}$ as a dopant to improve the photocatalytic performance of $\mathrm{V}_{2} \mathrm{O}_{5}$ and obtained the predicted improvement in performance [35]. It is well known that heterostructures formed by integrating two or more semiconductors can theoretically improve photocatalytic efficiency because the photogenerated electrons can migrate from a semiconductor with a higher conduction-band (CB) minimum to another with a lower CB minimum.

Besides being coupled with other semiconductors to improve the photocatalytic performance of the resulting composites [36,37], $\mathrm{MoO}_{3}$ has also been widely used because of its unique structure and chemical properties [10]. What will happen when $\mathrm{MoO}_{3}$ is used as the host and $\mathrm{V}_{2} \mathrm{O}_{5}$ as the dopant? In the present contribution, we explore the influence of a molar ratio of $\mathrm{V}$ to $\mathrm{Mo}, n(\mathrm{~V}) / n(\mathrm{Mo})$ on the structure and photocatalytic activity of the resulting $\mathrm{V}_{2} \mathrm{O}_{5} / \mathrm{MoO}_{3}$ composites. The $\mathrm{V}_{2} \mathrm{O}_{5} / \mathrm{MoO}_{3}$ composites are fabricated via electrospinning, a useful technique for the preparation of composites with controllable hierarchical features [38]. The effect of $n(\mathrm{~V}) / n(\mathrm{Mo})$ on the structure, morphology, surface properties, and optical absorption of the composites, as well as their application in the degradation of DMP are analyzed.

\section{Experimental}

\subsection{Preparation of catalysts}

All reagents were of analytical grade and used as purchased from commercial suppliers without further purification. $\mathrm{V}_{2} \mathrm{O}_{5} / \mathrm{MoO}_{3}$ composites with different $n(\mathrm{~V}) / n(\mathrm{Mo})$ were synthesized by the following electrospinning and calcination processes. Polyvinyl pyrrolidone (PVP, $1 \mathrm{~g}$ ) was dissolved in ethanol ( $9 \mathrm{~mL}$ ) and stirred for $10 \mathrm{~h}$ to form solution (A). Ammonium molybdate tetrahydrate $\left(\left(\mathrm{NH}_{4}\right)_{6} \mathrm{Mo}_{7} \mathrm{O}_{24} \cdot 4 \mathrm{H}_{2} \mathrm{O}, 0.4618 \mathrm{~g}\right)$ and ammonium metavanadate $\left(\mathrm{NH}_{4} \mathrm{VO}_{3}, 0.0382 \mathrm{~g}\right)$ $(n(\mathrm{~V}) / n(\mathrm{Mo})=1 / 8)$ were dissolved in $50 \%$ ethanol solution $(4$ $\mathrm{mL}$ ) and then stirred for $10 \mathrm{~h}$ to form solution (B). Solution (B) was added to solution $(A)$, and then the resulting mixture was stirred for $10 \mathrm{~h}$ at room temperature. A viscous gel of $\mathrm{PVP} /\left(\mathrm{NH}_{4}\right)_{6} \mathrm{Mo}_{7} \mathrm{O}_{24} / \mathrm{NH}_{4} \mathrm{VO}_{3}$ formed during stirring. The as-obtained gel was transferred to a syringe, and a piece of copper wire connected to a high-voltage generator was inserted into the gel. A direct current voltage of $16 \mathrm{kV}$ was applied for electrospinning. A piece of flat aluminum foil was placed $16 \mathrm{~cm}$ under the tip of the syringe to collect the composite fibers. The obtained composite fibers were calcined at a heating rate of 1 ${ }^{\circ} \mathrm{C} / \mathrm{min}$ and held for $3 \mathrm{~h}$ at 300,400 or $500{ }^{\circ} \mathrm{C}$ in air. Composites with $n(\mathrm{~V}) / n(\mathrm{Mo})=1 / 8,1 / 6,1 / 4,1 / 2$ and $1 / 1$, which are denoted as VM-8, VM-6, VM-4, VM-2 and VM-1, respectively, were prepared under the same conditions. For comparison, pure $\mathrm{MoO}_{3}$ and $\mathrm{V}_{2} \mathrm{O}_{5}$ photocatalysts were also prepared under the same conditions.

\subsection{Characterization}

The crystal structure of samples was determined by X-ray diffraction (XRD) patterns recorded on a Rigaku D/Max-IIB diffractometer with $\mathrm{Cu} K_{\alpha}(\lambda=0.15405 \mathrm{~nm})$ radiation at a scan rate of $4^{\circ} / \mathrm{min}$ in the range of $2 \theta=10^{\circ}-80^{\circ}$. The morphology of samples was observed by field-emission scanning electron microscopy (FE-SEM, FEI-Philips XL-30) and transmission electron microscopy (TEM, Philips T20ST). The specific surface areas (SSA) of samples were measured at liquid $\mathrm{N}_{2}$ temperature using the Brunauer-Emmett-Teller method (BET, JW-K). X-ray photoelectron spectra (XPS) were recorded on an ESCALAB-MKII photoelectron spectrometer with $\mathrm{Al} K_{\alpha}$ (1468.6 $\mathrm{eV})$ radiation as the excitation source. Ultraviolet-Visible diffuse reflectance spectra (UV-Vis DRS) were obtained by a Lambda 900 UV-Vis-NIR spectrophotometer (Perkin-Elmer). The identification of degradation intermediates of DMP was performed by high-performance liquid chromatography-tandem mass spectrometry (OA_SPE Waters Xevo TQ_S).

\subsection{Photocatalysis experiments}

Photocatalysis experiments using the composites were performed in a self-assembled photoreactor at room temperature. The photoreactor used a 500-W high-pressure xenon lamp as a visible-light source $(\lambda>420 \mathrm{~nm})$, which was surrounded by a water-cooling quartz jacket and with a UV cutoff filter. For the photocatalytic degradation of methylene blue (MB) solution, MB aqueous solution (10 mg/L, $100 \mathrm{~mL}$ ) and catalyst (50 mg) were stirred in the dark for ca. $30 \mathrm{~min}$ to let the catalyst disperse completely and establish an adsorption-desorption equilibrium between MB and catalyst. At given time intervals, $10-\mathrm{mL}$ aliquots of the reaction mixture were withdrawn and centrifuged; the absorption of the resulting clear solutions at $\lambda_{\max }=664 \mathrm{~nm}$ was examined using a UV-Vis 756B spectrophotometer. Photocatalytic degradation of DMP solution by the catalysts was tested under similar conditions. DMP solution (40 $\mathrm{mg} / \mathrm{L}, 60 \mathrm{~mL}$ ) and catalyst (100 mg) were stirred in the dark for ca. $30 \mathrm{~min}$. Every hour, a 10 -mL aliquot of the reaction mixture was withdrawn and centrifuged; the absorption of the clear solution at $\lambda_{\max }=230 \mathrm{~nm}$ was detect by a UV-Vis $756 \mathrm{~B}$ spectrophotometer. As control experiments, the photocatalytic degradation of both substrates was also tested in the absence of catalyst.

\section{Results and discussion}

\subsection{Structure and morphology}

The crystalline phases of pure $\mathrm{MoO}_{3}, \mathrm{~V}_{2} \mathrm{O}_{5}$, and the $\mathrm{V}_{2} \mathrm{O}_{5} / \mathrm{MoO}_{3}$ composites were analyzed by XRD. As shown in Fig. $1(\mathrm{a})$, all of peaks observed in the XRD patterns of the composites can be indexed to orthorhombic $\mathrm{MoO}_{3}$ (JCPDS 05-0508) 


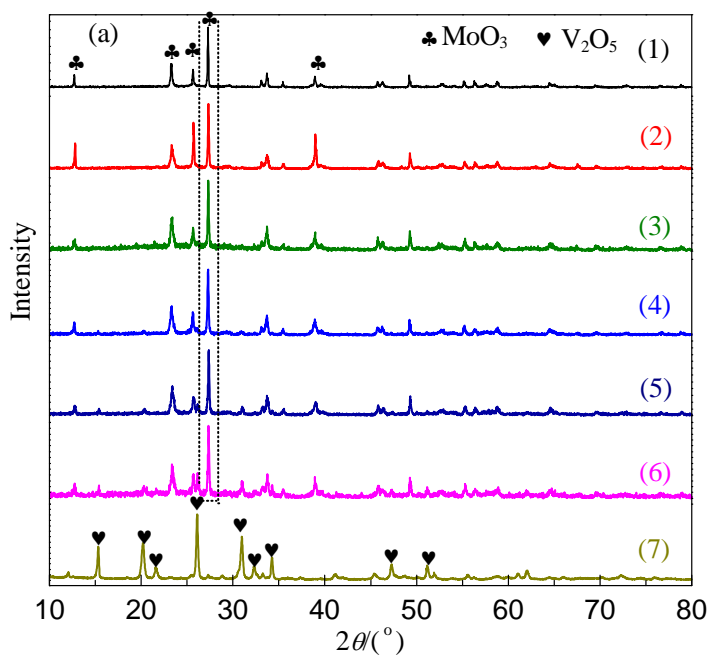

Fig. 1. (a) XRD patterns of (1) $\mathrm{MoO}_{3}$; (2) VM-8; (3) VM-6; (4) VM-4; (5) VM-2; (6) VM-1; (7) $\mathrm{V}_{2} \mathrm{O}_{5}$. (b) Enlarged view of the MoO $(021)$ peaks of (1) $\mathrm{MoO}_{3}$; (2) VM-8; (3) VM-6; (4) VM-4; (5) VM-2; (6) VM-1.

when $n(\mathrm{~V}) / n(\mathrm{Mo})<1 / 6$; no characteristic peaks corresponding to vanadium oxides are observed. When $n(\mathrm{~V}) / n(\mathrm{Mo})>1 / 6$, both the diffraction peaks of orthorhombic $\mathrm{MoO}_{3}$ (JCPDS 05-0508) and orthorhombic $\mathrm{V}_{2} \mathrm{O}_{5}$ (JCPDS 41-1426) are observed. The intensity of the peaks corresponding to orthorhombic $\mathrm{V}_{2} \mathrm{O}_{5}$ increased with $n(\mathrm{~V}) / n(\mathrm{Mo})$ (Fig. 1(a)). Fig. 1(b) depicts the amplified $\mathrm{MoO}_{3}$ (021) reflection of the samples. The $\mathrm{MoO}_{3}$ (021) peak shifted to larger diffraction angle as $n(\mathrm{~V}) / n(\mathrm{Mo})$ increased until VM-1, where the shift ceases. Fig. 1 indicates that when $n(\mathrm{~V}) / n(\mathrm{Mo})$ is low, $\mathrm{V}$ dopes into the $\mathrm{MoO}_{3}$ crystal lattice to form a V-doped $\mathrm{MoO}_{3}$ crystal. As the amount of $\mathrm{V}$ ions increases, $\mathrm{V}_{2} \mathrm{O}_{5}$ and $\mathrm{V}$-doped $\mathrm{MoO}_{3}$ crystals coexist, forming $\mathrm{V}_{2} \mathrm{O}_{5} / \mathrm{V}$-doped $\mathrm{MoO}_{3}$ heterojunctions. In this structure, $\mathrm{V}_{2} \mathrm{O}_{5}$ crystals should be dispersed on the surface of V-doped $\mathrm{MoO}_{3}$ crystals. Based on these results, it can be deduced that

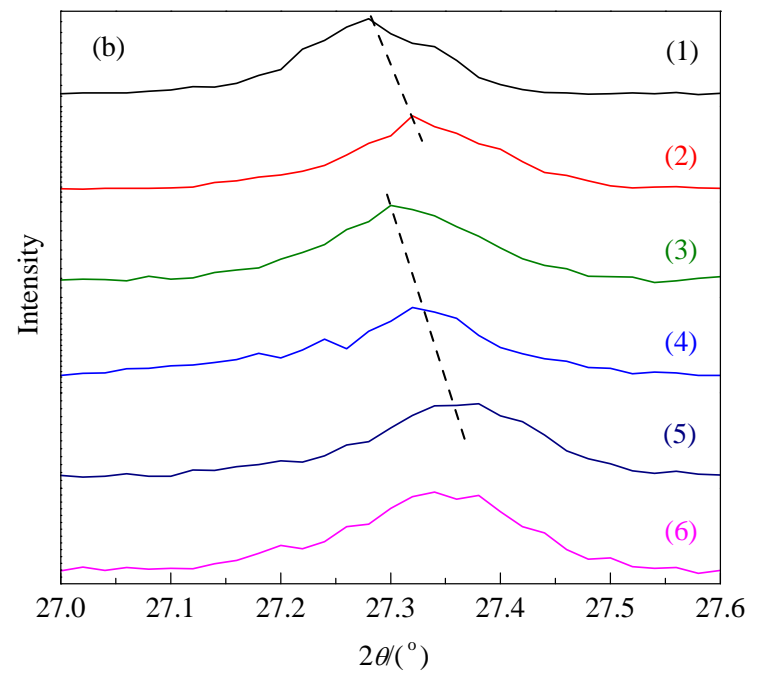

$\mathrm{V}_{2} \mathrm{O}_{5} / \mathrm{V}$-doped $\mathrm{MoO}_{3}$ heterojunctions form when $n(\mathrm{~V}) / n(\mathrm{Mo})>$ $1 / 6$.

For $\mathrm{VM}-2$, the theoretical $\mathrm{MoO}_{3}$ content $\left(f_{\mathrm{M}}\right)$ is $75.99 \%$; however, the experimental value is $80.55 \%$, which was obtained from the integrated intensities of the $\mathrm{MoO}_{3}$ diffraction line $\left(I_{\mathrm{M}}\right)$, and $\mathrm{V}_{2} \mathrm{O}_{5}$ diffraction line $\left(I_{\mathrm{V}}\right)$ using the following phase analysis equation [39]:

$$
f_{\mathrm{M}}=\frac{I_{\mathrm{M}}}{I_{\mathrm{M}}+1.875 I_{\mathrm{V}}}
$$

The experimental content of $\mathrm{MoO}_{3}$ in the $\mathrm{V}_{2} \mathrm{O}_{5} / \mathrm{MoO}_{3}$ composites is higher than the theoretical one, which supports that some $\mathrm{V}$ ions dope into the $\mathrm{MoO}_{3}$ lattice while others form $\mathrm{V}_{2} \mathrm{O}_{5}$ crystals or exist in other forms.

Figure 2 shows FE-SEM images of all samples, along with a TEM image and EDS data for VM-2. Flakes of crystalline $\mathrm{MoO}_{3}$
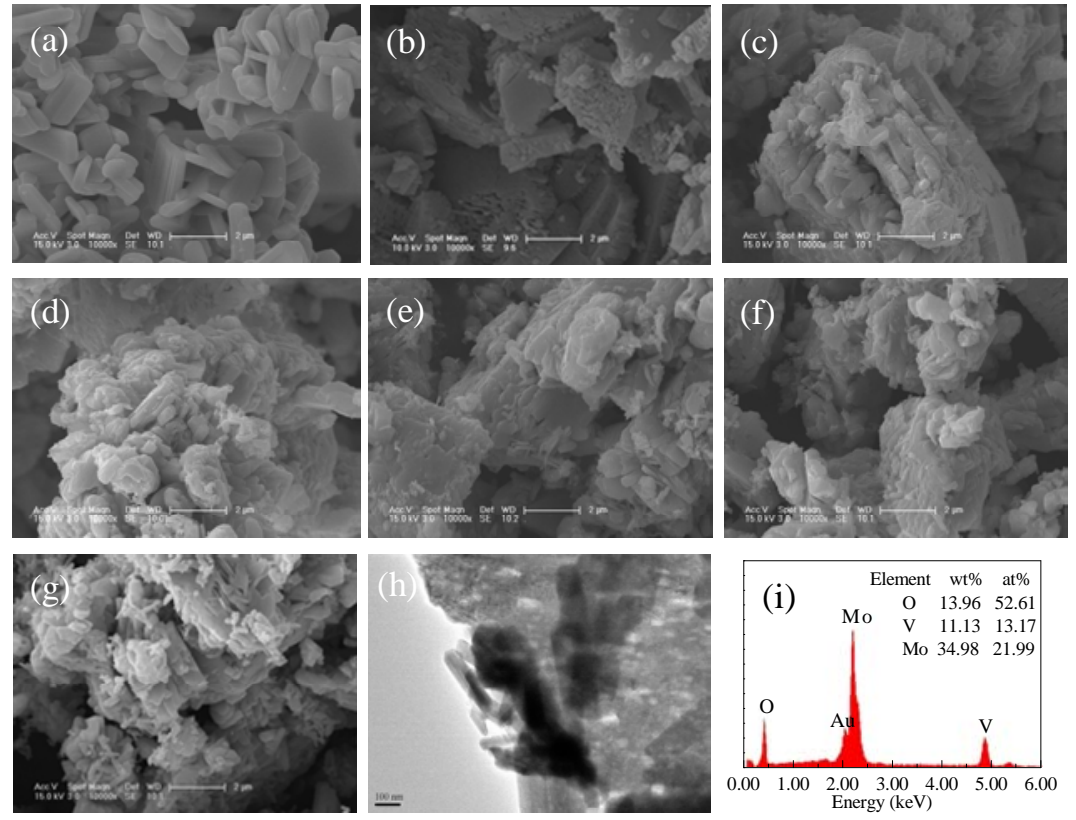

Fig. 2. FE-SEM images of (a) $\mathrm{MoO}_{3}$; (b) $\mathrm{V}_{2} \mathrm{O}_{5}$; (c) VM-8; (d) VM-6; (e) VM-4; (f) VM-2; (g) VM-1; (h) TEM images of VM-2; (i) EDS data of VM-2. 
have a smooth surface (Fig. 2(a)); crystalline $\mathrm{V}_{2} \mathrm{O}_{5}$ displays a block-like granular shape (Fig. 2(b)) [35]. As seen in Fig. 2 (c)-(g), the morphology of $\mathrm{V}_{2} \mathrm{O}_{5} / \mathrm{MoO}_{3}$ composites is different from that of pure $\mathrm{MoO}_{3}$ and tends toward the structure of pure $\mathrm{V}_{2} \mathrm{O}_{5}$ as $n(\mathrm{~V}) / n(\mathrm{Mo})$ increases with more and more $\mathrm{V}_{2} \mathrm{O}_{5}$ particles deposited on the $\mathrm{MoO}_{3}$ flakes. The TEM image of VM-2 clearly reveals that $\mathrm{V}_{2} \mathrm{O}_{5}$ particles have deeply rooted in the $\mathrm{MoO}_{3}$ flakes (Fig. 2(h)), indicating that heterojunctions have formed at the interface between $\mathrm{MoO}_{3}$ and $\mathrm{V}_{2} \mathrm{O}_{5}$. None of the samples show fiber morphology, which is ascribed to their calcination at high temperature [35]. The EDS data of VM-2 in Fig. 2(i) is consistent with the presence of Mo, V, and 0 elements and $n(\mathrm{~V}) / n(\mathrm{Mo})$ of around $1 / 2$, which is consistent with the nominal value. The Au signal can be attributed to the Au coating; no other impurities are observed.

SSA is an important factor that affects the photocatalytic activity of photocatalysts. This is because a large SSA aids absorption of light, organics and $\mathrm{OH}$ groups. Table 1 lists the SSAs of $\mathrm{MoO}_{3}, \mathrm{~V}_{2} \mathrm{O}_{5}$ and the $\mathrm{V}_{2} \mathrm{O}_{5} / \mathrm{MoO}_{3}$ composites. The SSA of pure $\mathrm{V}_{2} \mathrm{O}_{5}$ is much higher than that of pure $\mathrm{MoO}_{3}$. The SSA of VM-8 is lower than that of pure $\mathrm{MoO}_{3}$, which is attributed to the $\mathrm{V}_{2} \mathrm{O}_{5}$ particles blocking the secondary pores between $\mathrm{MoO}_{3}$ flakes. The SSA of the $\mathrm{V}_{2} \mathrm{O}_{5} / \mathrm{MoO}_{3}$ composites increases gradually with $n(\mathrm{~V}) / n(\mathrm{Mo})$ from $1 / 8$ to $1 / 1$. The increase of SSA of the composites may be caused by the formation and growth in the number or size of $\mathrm{V}_{2} \mathrm{O}_{5}$ particles.
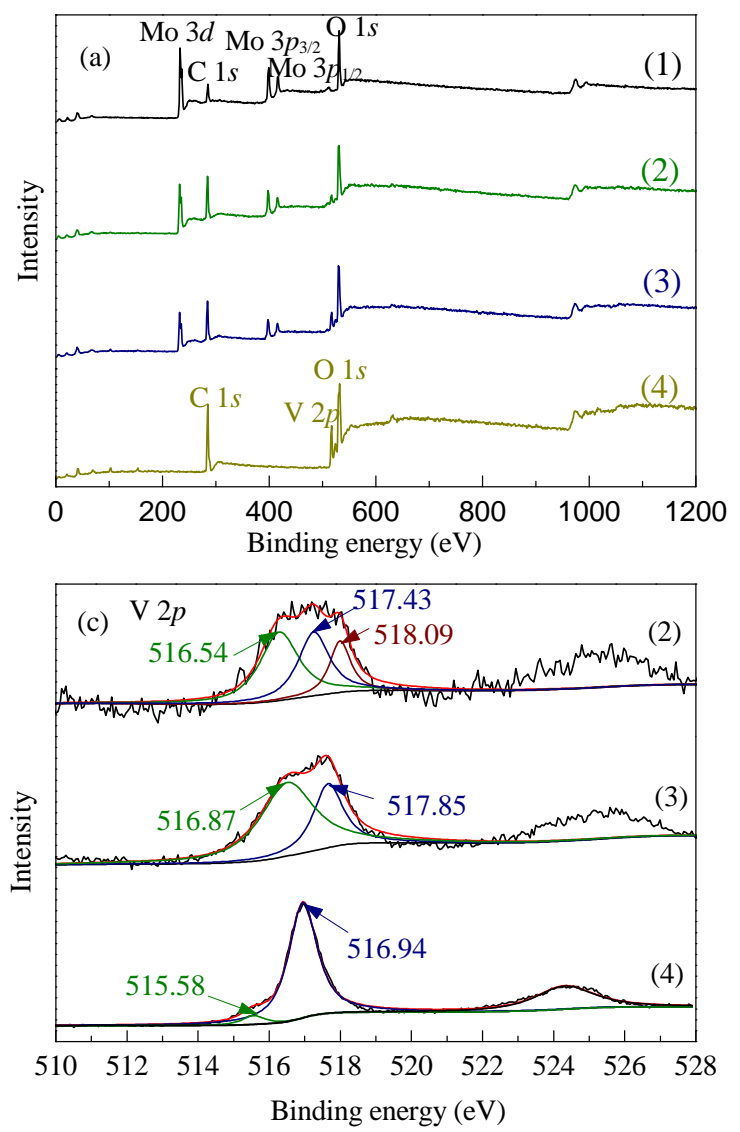

\subsection{Surface properties and optical absorption}

To explore the surface composition and chemical states of the $\mathrm{V}_{2} \mathrm{O}_{5} / \mathrm{MoO}_{3}$ composites in more detail, the samples were characterized by XPS (Fig. 3). The peaks in the spectra are assigned to $\mathrm{O}, \mathrm{V}, \mathrm{Mo}$, and $\mathrm{C}$; no other impurities were found. The $\mathrm{C}$ impurity originates from a carbon-based contaminant (Fig. 3(a)). Fig. 3(b) presents the Mo $3 d$ spectra of pure $\mathrm{MoO}_{3}$, VM-6 and VM-2. The main peaks centered at 232 and $235 \mathrm{eV}$ indicate that Mo exists as $\mathrm{Mo}^{6^{+}}$ions in the samples [40]. Fig. 3(c) shows the $\mathrm{V} 2 p$ spectra of $\mathrm{VM}-6, \mathrm{VM}-2$ and pure $\mathrm{V}_{2} \mathrm{O}_{5}$. For pure $\mathrm{V}_{2} \mathrm{O}_{5}$, the peaks at 515.58 and $516.94 \mathrm{eV}$ correspond to $\mathrm{V}^{3+}$ and $\mathrm{V}^{5+}$ ions, respectively, indicating that there are $\mathrm{V}^{3+}$ and $\mathrm{V}^{5+}$ ions in the sample [41]. Meanwhile, the peaks of VM-6 at 516.54, 517.43, and $518.09 \mathrm{eV}$ are consistent with $\mathrm{V}^{3+}, \mathrm{V}^{4+}$, and $\mathrm{V}^{5+}$ ions, respectively. The peaks of VM-2 at 516.87 and $517.85 \mathrm{eV}$ correspond to $\mathrm{V}^{4+}$ and $\mathrm{V}^{5+}$ ions [25], respectively. The presence of $\mathrm{V}^{3+}$ and $\mathrm{V}^{4+}$ ions as well as $\mathrm{V}^{5+}$ ones is normal in semiconductors containing $\mathrm{V}_{2} \mathrm{O}_{5}$ [42]. Moreover, the fitted Gaussian Lorentzian peaks of V $2 p$ spectra for VM-6 and VM-2 in Fig. 3(c) show that the binding energy of different valence states of $\mathrm{V}$ increases slightly compared with those of pure $\mathrm{V}_{2} \mathrm{O}_{5}$. Compared with that of pure $\mathrm{MoO}_{3}$, the binding energy of Mo in VM- 6 and VM-2 decreases slightly (Fig. 3(b)). Both of these binding energy variations indicate that the chemical environments of $\mathrm{V}$ and Mo have changed in the composites compared with in the pure materials because of doping or heterostructure formation. Notably, the
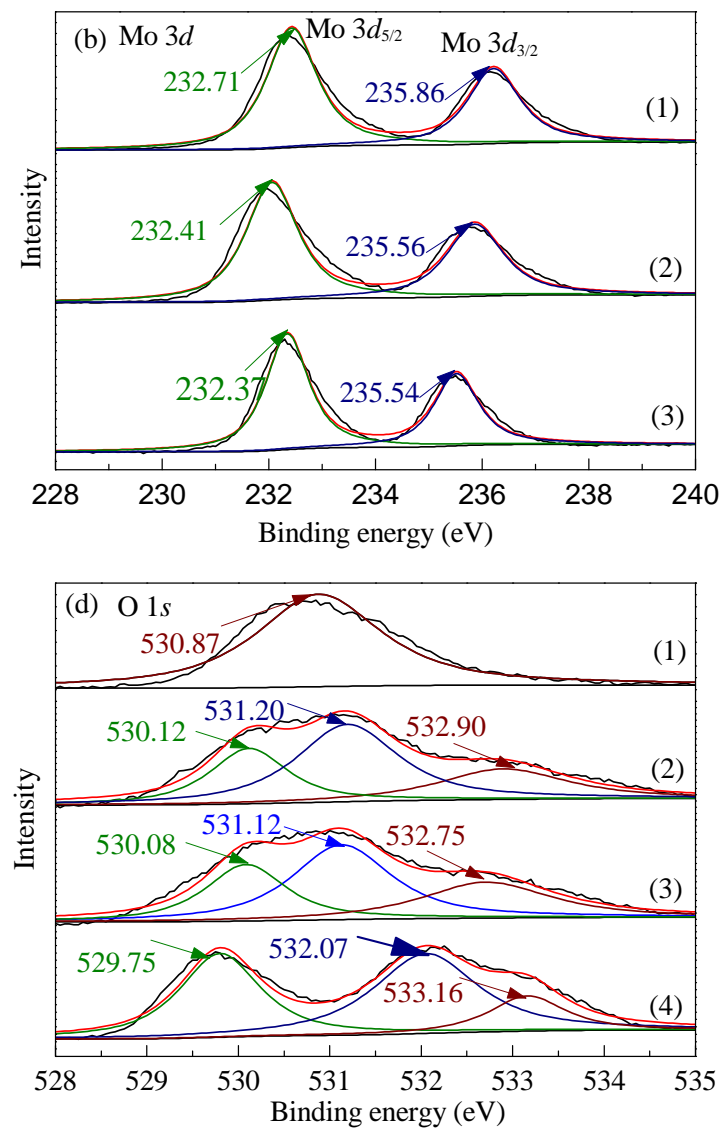

Fig. 3. (a) XPS spectra, and (b) Mo 3d, (c) V $2 p$ and (d) $01 s$ spectra of the samples. (1) $\mathrm{MoO}_{3}$; (2) VM-6; (3) VM-2; (4) $\mathrm{V}_{2} \mathrm{O}_{5}$. 
presence of $\mathrm{V}$ ions of various valence can lead to formation of more oxygen vacancies, which enhances the surface adsorption ability of $\mathrm{V}_{2} \mathrm{O}_{5} / \mathrm{MoO}_{3}$ composites for water and organic species [22].

The 01 s spectra of the samples are provided in Fig. 3(d). For pure $\mathrm{MoO}_{3}$, the peak at $530.87 \mathrm{eV}$ is attributed to crystal lattice oxygen $\left(\mathrm{O}_{\mathrm{Mo}-0}\right)$. The peaks of pure $\mathrm{V}_{2} \mathrm{O}_{5}$ at 529.75 , 532.07, and $533.16 \mathrm{eV}$ correspond to crystal lattice oxygen (Ov-0), surface hydroxyl groups ( $\mathrm{O}_{\mathrm{O}-\mathrm{H}}$ ) [43], and adsorbed water on the surface of $\mathrm{V}_{2} \mathrm{O}_{5}$, respectively. The peaks of VM- 6 and VM-2 at 530 and $531 \mathrm{eV}$ are ascribed to crystal lattice oxygen, $\mathrm{OV}_{\mathrm{V}} \mathrm{O}$ and $\mathrm{O}_{\mathrm{Mo}-\mathrm{O}}$, respectively, while that at $533 \mathrm{eV}$ originates from adsorbed water on the surface of the composites [22].

To examine the optical properties of the samples, their UV-Vis DRS were recorded over the wavelength range of 200-800 $\mathrm{nm}$ at room temperature. As shown in Fig. 4, pure $\mathrm{MoO}_{3}$ and $\mathrm{V}_{2} \mathrm{O}_{5}$ display absorption edges at about 440 and 580 $\mathrm{nm}$, respectively. The absorption edges of VM-8, VM-6, VM-4, VM-2 and VM-1 show a marked red shift compared with that of pure $\mathrm{MoO}_{3}$, appearing at 530, 540, 540, 550, and $560 \mathrm{~nm}$, respectively. VM-6 and VM-4 show almost the same absorption edge, which may be because VM- 6 and VM-4 are at the transition point between $\mathrm{V}$-doped composite and heterojunction formation. The band gaps of the samples were calculated using Equation (2) and are listed in Table 1.

$$
E_{g}=h c / \lambda_{g}=1240 / \lambda_{g}
$$

As shown in Table 1, the band gaps of the samples decreased from 2.82 to $2.21 \mathrm{eV}$ when $n(\mathrm{~V}) / n(\mathrm{Mo})$ in $\mathrm{V}_{2} \mathrm{O}_{5} / \mathrm{MoO}_{3}$ composites increased from $0 / 1$ to $1 / 1$. It is obvious that either V-doping or heterojunctions can effectively extend the photoresponse range and decrease the band gap of the composites, which should improve their photocatalytic performance, particularly under visible-light irradiation.

\subsection{Photocatalytic activity and mechanism}

The photocatalytic degradation of MB was chosen as a mod-

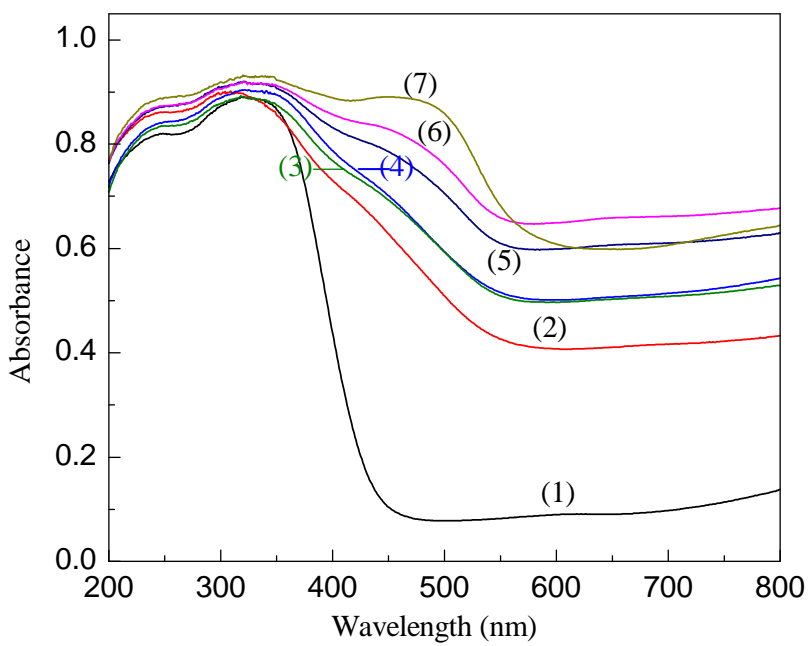

Fig. 4. UV-Vis diffuse reflectance spectra of (1) $\mathrm{MoO}_{3}$; (2) VM-8; (3) VM-6; (4) VM-4; (5) VM-2; (6) VM-1; (7) $\mathrm{V}_{2} \mathrm{O}_{5}$
Table 1

SSA, band gap (BG), photodegradation efficiency (PE) of MB, generation rate (GR) of phthalic acid over different samples.

\begin{tabular}{lcccc}
\hline Sample & $\mathrm{SSA}\left(\mathrm{m}^{2} / \mathrm{g}\right)$ & $\mathrm{BG}(\mathrm{eV})$ & $\mathrm{PE} \mathrm{( \% )*}$ & $\mathrm{GR}(\%)^{* *}$ \\
\hline $\mathrm{MoO}_{3}$ & 0.7680 & 2.82 & 47.62 & 64.58 \\
$\mathrm{VM}-8$ & 0.6932 & 2.34 & 65.56 & - \\
$\mathrm{VM}-6$ & - & 2.30 & 73.60 & 75.57 \\
$\mathrm{VM}-4$ & 1.5374 & 2.30 & 81.68 & - \\
$\mathrm{VM}-2$ & - & 2.25 & 89.23 & 82.20 \\
$\mathrm{VM}-1$ & 2.6664 & 2.21 & 78.16 & - \\
$\mathrm{V}_{2} \mathrm{O}_{5}$ & 8.5757 & 2.13 & 49.95 & 65.20 \\
\hline
\end{tabular}

*After irradiation for $140 \mathrm{~min}$; ${ }^{* *}$ After irradiation for $5 \mathrm{~h}$.

el reaction to evaluate the photocatalytic performance of the $\mathrm{V}_{2} \mathrm{O}_{5} / \mathrm{MoO}_{3}$ composites and determine the optimal $n(\mathrm{~V}) / n(\mathrm{Mo})$. Fig. 5 shows the photodegradation of MB without catalyst and over different photocatalysts under visible-light irradiation. The self-degradation of MB was $7.52 \%$, and the photodegradation over all samples (after subtraction of the photodegradation of MB without photocatalyst) are listed in Table 1.

All the $\mathrm{V}_{2} \mathrm{O}_{5} / \mathrm{MoO}_{3}$ composites show higher photocatalytic activity than pure $\mathrm{MoO}_{3}$ and $\mathrm{V}_{2} \mathrm{O}_{5} . \mathrm{V}_{2} \mathrm{O}_{5} / \mathrm{V}$-doped $\mathrm{MoO}_{3}$ samples (Fig. 5(4, 5, 6)) exhibit better photocatalytic performance than V-doped $\mathrm{MoO}_{3}$ samples (Fig. 5(2, 3)). Moreover, VM-2 displays the highest photocatalytic activity of the $\mathrm{V}_{2} \mathrm{O}_{5} / \mathrm{MoO}_{3}$ composites; therefore, the optimal $n(\mathrm{~V}) / n$ (Mo) should be $1 / 2$.

The photocatalytic activity and efficiency of a semiconductor are related to many factors, including band gap and SSA [20]. Under the same reaction conditions, the narrower band gap, the higher the photocatalytic efficiency, and the larger the SSA, the higher the photocatalytic activity. Therefore, the photocatalytic activity and efficiency of VM- 6 are higher than that of VM-8 because of the narrower band gap and larger SSA of VM-6. Because VM-4 has a larger SSA than VM-6, the photocatalytic activity of VM-4 is slightly higher than that of VM-6 even though the band gaps of VM-4 and VM- 6 are almost the same. When $n(\mathrm{~V}) / n(\mathrm{Mo})$ is too high, the excess $\mathrm{V}_{2} \mathrm{O}_{5}$ on the $\mathrm{MoO}_{3}$ surface may cover active sites [41], which is why VM-1

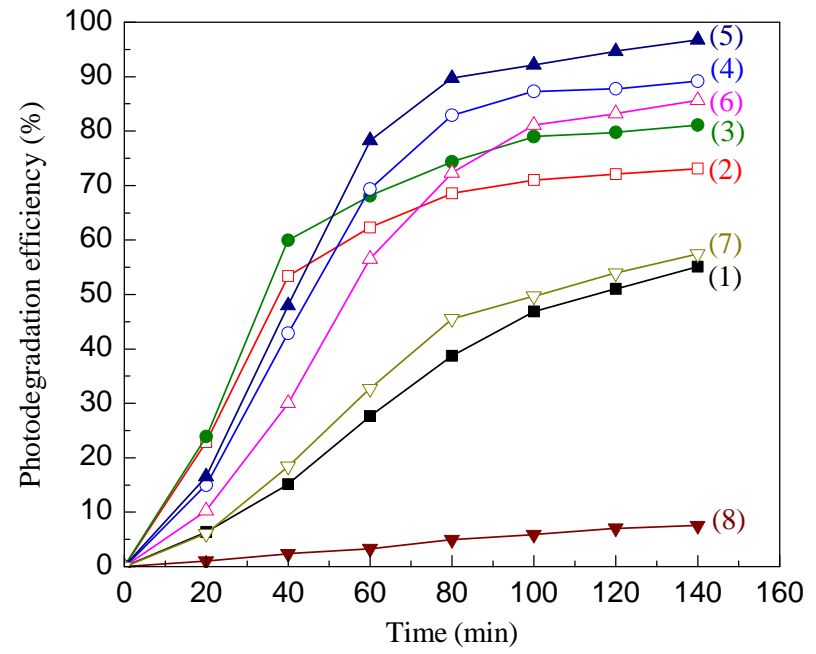

Fig. 5. Photodegradation of MB over (1) $\mathrm{MoO}_{3}$; (2) VM-8; (3) VM-6; (4) VM-4; (5) VM-2; (6) VM-1; (7) $\mathrm{V}_{2} \mathrm{O}_{5}$; (8) No photocatalyst. 
shows lower photocatalytic activity than VM-2. Overall, the suitable $n(\mathrm{~V}) / n(\mathrm{Mo})$ of $\mathrm{VM}-2$ resulting in a narrow band gap and large SSA are responsible for its high photocatalytic activity.

To investigate the photocatalytic performance of the composites in greater detail, we examined their ability to photodegrade DMP in water. It has been reported that one of the main intermediates formed in the photodegradation of DMP is phthalic acid [2]. Fig. 6 shows the generation rate of phthalic acid over different samples under visible-light irradiation. The self-degradation of DMP does not occur under the same conditions. VM-2 shows higher photocatalytic activity than pure $\mathrm{MoO}_{3}, \mathrm{~V}_{2} \mathrm{O}_{5}$, and VM- 6 . This further confirms that the heterostructures have excellent photocatalytic activity, and can effectively photodegrade organic species in water. Among the samples, VM-2 shows the highest photocatalytic activity, with its degradation efficiency of MB reaching up to $89.23 \%$. The composites also show excellent catalytic performance in the photodegradation of DMP in water. As discussed above, the $\mathrm{V}_{2} \mathrm{O}_{5} / \mathrm{MoO}_{3}$ composites exhibit better photocatalytic performance than pure $\mathrm{MoO}_{3}$ and $\mathrm{V}_{2} \mathrm{O}_{5}$, which is attributed to a synergistic effect between doping and heterostructures: the dopant effectively narrows the band gap of $\mathrm{MoO}_{3}$ and heterostructures improve the separation rate of photogenerated electron-hole pairs.

The XRD results indicated that $\mathrm{V}$ was doped into the crystal lattice of $\mathrm{MoO}_{3}\left(\mathrm{~V}_{2} \mathrm{O}_{5} \stackrel{2 \mathrm{MoO}_{3}}{\longrightarrow} 2 \mathrm{~V}_{\mathrm{Mo}}^{\prime}+\mathrm{V}_{\mathrm{O}}^{*}+5 \mathrm{O}_{\mathrm{O}}\right)$ to different degrees in the samples; XPS results revealed that $\mathrm{V}$ ions exist in multiple valence states. The existence of a V $3 d$ impurity level narrows the band gap of pure $\mathrm{MoO}_{3}$, shortening the transmission distance of charged particles $[25,26]$. Both the electron transition from the valence band $(02 p)$ to the $t_{2 g}$ level of the $\mathrm{V} 3 d$ orbitals and the $d-d$ transition of $\mathrm{V}$ may be driven by absorption of visible light [44]. This is the reason why all of the $\mathrm{V}_{2} \mathrm{O}_{5} / \mathrm{MoO}_{3}$ composites show good photocatalytic performance under visible-light irradiation.

Because $\mathrm{V}_{2} \mathrm{O}_{5}$ particles are in close contact with the $\mathrm{V}$-doped $\mathrm{MoO}_{3}$ flakes, staggered energy levels may form between the heterojunctions. According to the known mechanism of electronic transmission and a previous report [33], we propose a

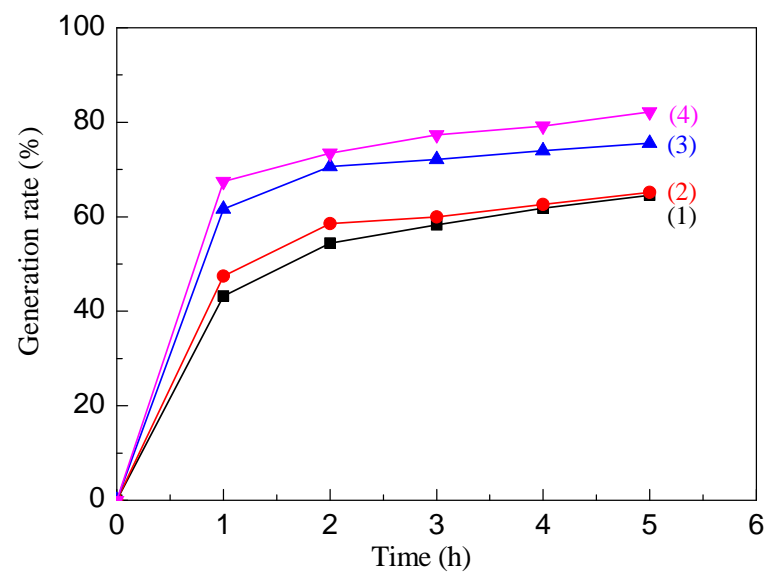

Fig. 6. Generation rates of phthalic acid over (1) $\mathrm{MoO}_{3}$; (2) $\mathrm{V}_{2} \mathrm{O}_{5}$; (3) VM-6; (4) VM-2.

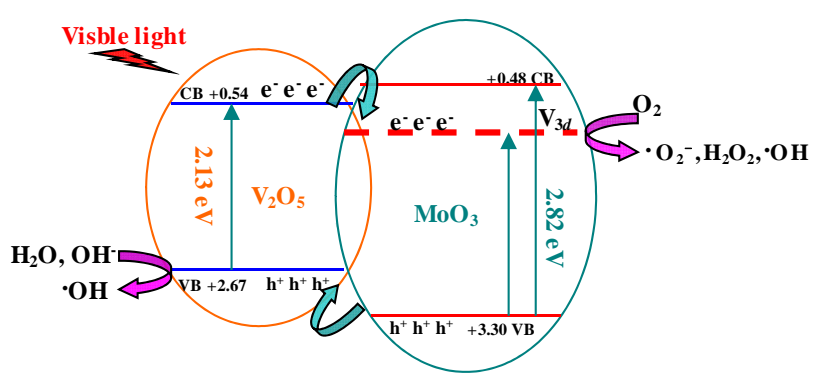

Fig. 7. Photocatalytic mechanism of $\mathrm{V}_{2} \mathrm{O}_{5} / \mathrm{V}$-doped $\mathrm{MoO}_{3}$ composites.

possible photocatalytic mechanism for $\mathrm{V}_{2} \mathrm{O}_{5} / \mathrm{V}$-doped $\mathrm{MoO}_{3}$ particles, which is outlined in Fig. 7. The potentials of the $\mathrm{CB}$ and valence band (VB) of the semiconductors in Fig. 7 can be evaluated by Equation (3) [45].

$$
E_{\mathrm{CB}}^{0}=X-E^{\mathrm{c}}-1 / 2 E_{\mathrm{g}}
$$

where $X$ is the absolute electronegativity of the semiconductor, $E^{c}$ is the energy of free electrons on the hydrogen scale $(\sim 4.5$ $\mathrm{eV}$ ), and $E_{\mathrm{g}}$ is the band gap energy of the semiconductor.

When $\mathrm{V}_{2} \mathrm{O}_{5} / \mathrm{V}$-doped $\mathrm{MoO}_{3}$ particles are irradiated with visible light, the electrons on the surface of $\mathrm{V}_{2} \mathrm{O}_{5}$ and $\mathrm{V}$-doped $\mathrm{MoO}_{3}$ are excited simultaneously. The photogenerated electrons of photoexcited $\mathrm{V}_{2} \mathrm{O}_{5}$ might inject into the $\mathrm{CB}$ of $\mathrm{MoO}_{3}$ of lower impurity energy level than that of $\mathrm{V}_{2} \mathrm{O}_{5}$, which results in a large number of electrons accumulating in $\mathrm{MoO}_{3}$. The oxygen species adsorbed on the catalyst surface then accept electrons to form superoxide radical anions $\left(\cdot \mathrm{O}_{2}{ }^{-}\right)$, hydrogen peroxide $\left(\mathrm{H}_{2} \mathrm{O}_{2}\right)$, and hydroxyl radicals $(\cdot \mathrm{OH})$ [4]. Meanwhile, the holes generated in the $\mathrm{VB}$ of $\mathrm{MoO}_{3}$ can be easily transferred into the $\mathrm{VB}$ of $\mathrm{V}_{2} \mathrm{O}_{5}$ because the $\mathrm{VB}$ potential of $\mathrm{V}_{2} \mathrm{O}_{5}$ is higher than that of $\mathrm{MoO}_{3}$. Overall, this promotes the separation of electron-hole pairs and lowers the probability of electron-hole recombination. Furthermore, the accumulated holes could facilitate formation of $\cdot \mathrm{OH}$ [22]. $\cdot \mathrm{O}_{2}{ }^{-}$and $\cdot \mathrm{OH}$ are known to be mainly responsible for the photocatalytic degradation of organic species, and they reacted with MB or DMP adsorbed on the catalyst surface to produce $\mathrm{CO}_{2}, \mathrm{H}_{2} \mathrm{O}$ and other substances [25,37]. The specific catalytic processes are as follows:

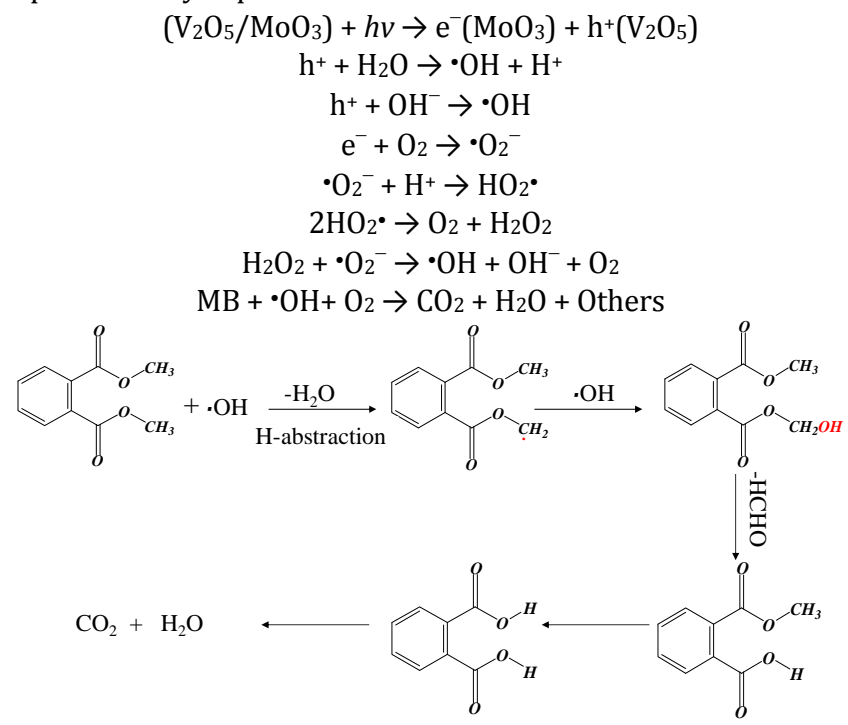

The MB adsorbed on the catalyst surface can also act as a 
photosensitizer, absorbing visible light and transferring electrons to the CB [46]. This may be the reason why the photocatalytic degradation efficiency of MB is higher than that of DMP over the catalysts.

\section{Conclusions}

$\mathrm{V}_{2} \mathrm{O}_{5} / \mathrm{MoO}_{3}$ composite photocatalysts have been prepared by a simple process. The resulting composites include both doping and heterostructures, which enhance their photocatalytic performance. Results indicate that the photocatalytic activity of the $\mathrm{V}_{2} \mathrm{O}_{5} / \mathrm{MoO}_{3}$ composites is higher than that of pure $\mathrm{MoO}_{3}$ for the degradation of MB and DMP under visible-light irradiation. The optimal $n(\mathrm{~V}) / n(\mathrm{Mo})$ is $1 / 2$, and the degradation efficiency of MB over the catalyst with this ratio reached 89.23\%. The catalysts also showed excellent catalytic performance for the photodegradation of DMP.

\section{References}

[1] Xu Z W, Zhang W M, Lü L, Pan B C, Lan P, Zhang Q X. Environ Sci Technol, 2010, 44: 3130

[2] An T C, Gao Y P, Li G Y, Kamat P V, Peller J, Joyce M V. Environ Sci Technol, 2014, 48: 641

[3] Chang C F, Man C Y. Ind Eng Chem Res, 2011, 50: 11620

[4] Zhang M Y, Shao C L, Zhang P, Su C Y, Zhang X, Liang P P, Sun Y Y, Liu Y C. J Hazard Mater, 2012, 225-226: 155

[5] Shang M, Wang W Z, Sun S M, Zhou L, Zhang L. J Phys Chem C, 2008, 112: 10407
[6] Gomathi Devi L, Kavitha R. RSC Adv, 2014, 4: 28265

[7] Ajmal A, Majeed I, Malik R N, Idriss H, Nadeem M A. RSC Adv, 2014, 4: 37003

[8] Lee S C, Lee H U, Lee S M, Lee G, Hong W G, Lee J, Kim H J. Mater Lett, 2012, 79: 191

[9] Ruzimuradov O, Nurmanov S, Hojamberdiev M, Prasad R M, Gurlo A, Broetz J, Nakanishi K, Riedel R. Mater Lett, 2014, 116: 353

[10] De Barros Santos E, Sigoli F A, Mazali I O.J Solid State Chem, 2012, 190: 80

[11] Cai L L, Rao P M, Zheng X L. Nano Lett, 2011, 11: 872

[12] Pan W Z, Tian R Y, Jin H, Guo Y J, Zhang L P, Wu X C, Zhang L N, Han Z H, Liu G Y, Li J B, Rao G H, Wang H F, Chu W G. Chem Mater, 2010, 22: 6202

[13] Elder S H, Cot F M, Su Y, Heald S M, Tyryshkin A M, Bowman M K, Gao Y, Joly A G, Balmer M L, Kolwaite Ana C, Magrini K A, Blake D M. J Am Chem Soc, 2000, 122: 5138

[14] Zeng M, Yin H H, Yu K. Chem Eng J, 2012, 188: 64

[15] Su J, Zou X X, Li G D, Wei X, Yan C, Wang Y N, Zhao J, Zhou L J, Chen J S. J Phys Chem C, 2011, 115: 8064

[16] Zou C W, Rao Y F, Alyamani A, Chu W, Chen M J, Patterson D A, Emanuelsson E A C, Gao W. Langmuir, 2010, 26: 11615

[17] Abazari R, Mahjoub A R, Saghatforoush L A, Sanati S. Mater Lett, 2014, 133: 208

[18] Sadale S B, Noda K, Kobayashi K, Yamada H, Matsushige K. Thin Solid Films, 2012, 520: 3847

[19] Zhang D Q, Wang S L, Zhu J, Li H X, Lu Y F. Appl Catal B, 2012, 123-124: 398

[20] Cao T P, Li Y J, Wang C H, Wei L M, Shao C L, Liu Y C. Mater Res Bull, 2010, 45: 1406

[21] Wang Q, Geng B Y, Wang S Z. Environ Sci Technol, 2009, 43: 8968

[22] Su C Y, Shao C L, Liu Y C. J Colloid Interf Sci, 2011, 359: 220

\section{Graphical Abstract}

Chin. J. Catal., 2015, 36: 2194-2202 doi: 10.1016/S1872-2067(15)61002-6

\section{Characterization of $\mathrm{V}_{2} \mathrm{O}_{5} / \mathrm{MoO}_{3}$ composite photocatalysts prepared via electrospinning and their photodegradation activity for dimethyl phthalate}

Hongyuan Chuai, Defeng Zhou*, Xiaofei Zhu, Zhaohui Li, Weiping Huang*

Nankai University; Changchun University of Technology

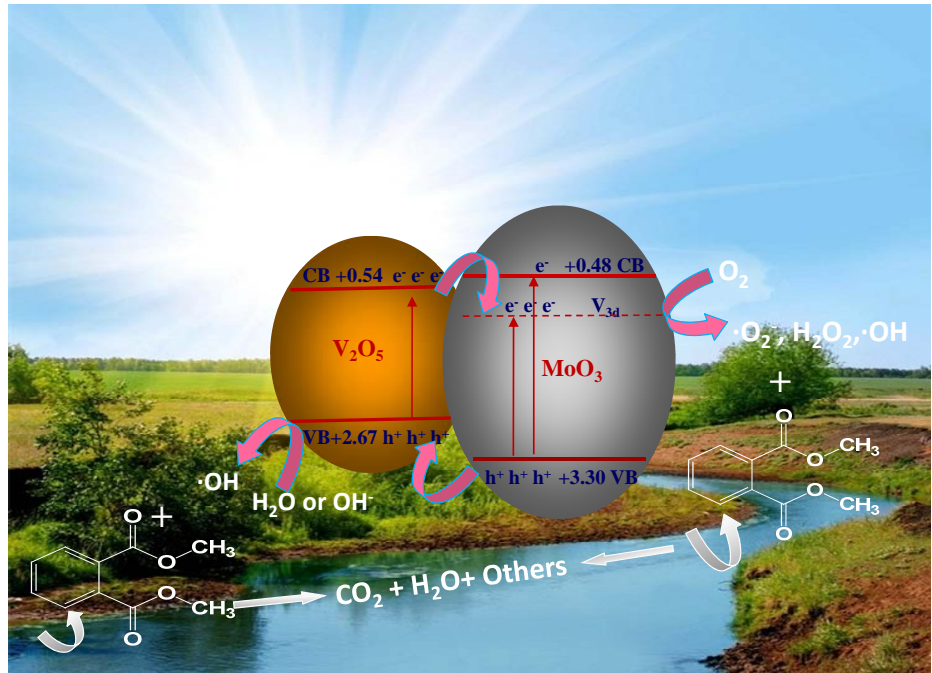

$\mathrm{V}_{2} \mathrm{O}_{5}$ /V-doped $\mathrm{MoO}_{3}$, which was characterized systematically, displays enhanced activity for photodegradation of methylene blue and dimethyl phthalate under visible light irradiation. The optimal molar ratio of $\mathrm{V}$ to Mo is around 1:2. 
[23] Wang L, Wei H W, Fan Y J, Gu X, Zhan J H.J Phys Chem C, 2009, 113: 14119

[24] Zhu B L, Sui Z M, Chen X, Wang S R, Zhang S M, Wu S H, Huang W P. Chin Sci Bull, 2005, 50: 711

[25] Zhang Z Y, Shao C L, Zhang L N, Li X H, Liu Y C. J Colloid Interf Sci, 2010, 351: 57

[26] Song J J, Zhu B L, Zhao W L, Hu X J, Shi Y K, Huang W P.J Nanoparticle Res, 2013, 15: 1494/1

[27] An H Q, He X L, Li J Q, Zhao L Z, Chang C, Zhang S H, Huang W P. New J Chem, 2015, 39: 4611

[28] Li Y F, Xu D H, Oh J I, Shen W Z, Li X, Yu Y. ACS Catal, 2012, 2: 391

[29] An H Q, Hu X J, Zhu B L, Song J J, Zhao W L, Zhang S M, Huang W P. Mater Sci Poland, 2013, 31: 531

[30] Yu J C, Ho W K, Yu J G, Yip H, Wong P K, Zhao J C. Environ Sci Technol, 2005, 39: 1175

[31] Chen X B, Liu L, Yu P Y, Mao S S. Science, 2011, 331: 746

[32] Wang F L, Jiang Y J, Gautam A, Li Y R, Amal R. ACS Catal, 2014, 4: 1451

[33] Yu C L, Yang K, Shu Q, Yu J C, Cao F F, Li X. Chin J Catal (车长林, 杨 凯, 舒庆, Yu J C, 操芳芳, 李金金. 催化学报), 2011, 32: 555

[34] Sherly E D, Vijaya J J, Kennedy L J. Chin J Catal (催化学报), 2015, 36: 1263
[35] Chuai H Y, Zhou D F, Zhu X F, Yang G C, Li Z H. Chem J Chin Univ, 2014, 35: 941

[36] Navgire M, Yelwande A, Tayde D, Arbad B, Lande M. Chin J Catal (催化学报), 2012, 33: 261

[37] Lam S M, Sin J C, Abdullah A Z, Mohamed A R. J Mol Catal A, 2013, 370: 123

[38] Ostermann R, Li D, Yin Y D, McCann J T, Xia Y N. Nano Lett, 2006, 6: 1297

[39] Kim Y S, Song M Y, Park E S, Chin S, Bae G N, Jurng J. Appl Biochem Biotechnol, 2012, 168: 1143

[40] Patil C E, Jadhav P R, Tarwal N L, Deshmukh H P, Karanjkar M M, Patil P S. Mater Chem Phys, 2011, 126: 711

[41] Wang Y, Zhang J W, Liu L X, Zhu C Q, Liu X Q, Su Q. Mater Lett, 2012, 75: 95

[42] Chen F, Wang J, Xu J Q, Zhou X P. Appl Catal A, 2008, 348: 54

[43] Chin S M, Park E S, Kim M S, Bae G N, Jurng J S. Mater Lett, 2012, 75: 57

[44] Tian B Z, Li C Z, Gu F, Jiang H B, Hu Y J, Zhang J L. Chem Eng J, 2009, 151: 606

[45] Wu Z B, Dong F, Liu Y, Wang H Q. Catal Commun, 2009, 11: 82

[46] Wang P, Wang J, Ming T S, Wang X F, Yu H G, Yu J G, Wang Y G, Lei M. Appl Mater Interf, 2013, 5: 2924

\title{
静电纺丝法制备的 $\mathrm{V}_{2} \mathrm{O}_{5} / \mathrm{MoO}_{3}$ 复合光催化剂的表征及其 光催化降解邻苯二甲酸二甲酯活性
}

\author{
揣宏媛 ${ }^{\mathrm{a}}$, 周德风年, 朱晓飞 ${ }^{\mathrm{b}}$, 李朝辉 ${ }^{\mathrm{b}}$, 黄唯平 ${ }^{\mathrm{a}, \#}$ \\ $\mathrm{a}$ 南开大学化学学院, 天津化学化工协同创新中心, 天津金属分子基材料化学重点实验室, 天津 300071 \\ ${ }^{\mathrm{b}}$ 长春工业大学化学与生命科学学院, 吉林长春130012
}

摘要: 邻苯二甲酸二甲酯是一种干扰人体内分泌系统的化学物质, 尽管对人体具有潜在危害, 目前仍做为塑料、醋酸乙烯酯、纤 维素等生产过程中的添加剂而广泛使用. 伴随着邻苯二甲酸二甲酯的生产和应用, 自然界不可避免地受其污染. 因此, 如何有效 降解排放在环境中的邻苯二甲酸二甲酯以减少其对人类的不利影响成为化学研究者的重要任务. 通过半导体光催化剂高效利用 太阳能光催化降解邻苯二甲酸二甲酯是一种有效方法. $\mathrm{TiO}_{2}$ 等半导体光催化剂由于光催化过程中产生的电子-空穴对极易复合导 致其催化效率不高, 减少光生电子-空穴对复合率进而提高光量子效率的方法有金属掺杂、非金属掺杂、表面敏化、半导体复合 等多种手段. 其中, $\mathrm{MoO}_{3}$ 由于其独特的结构和化学性质广泛应用于光催化领域, 并常作为耦合剂与其他半导体 $\left(\right.$ 如 $\mathrm{TiO}_{2}$ ) 复合以提 高光催化活性. 在我们以前的工作中, 曾使用 $\mathrm{MoO}_{3}$ 做为耦合剂与 $\mathrm{V}_{2} \mathrm{O}_{5}$ 复合, 实验结果证明 $\mathrm{MoO}_{3}$ 与 $\mathrm{V}_{2} \mathrm{O}_{5}$ 复合形成异质结构有效提 高了 $\mathrm{V}_{2} \mathrm{O}_{5}$ 的光催化效率. $\mathrm{MoO}_{3}$ 由于其带隙较宽(约 $2.90 \mathrm{eV}$ ), 对太阳光利用率不高, 以及电子-空穴对极易复合导致 $\mathrm{MoO}_{3}$ 实际光催 化活性并不好. 因此, 我们考虑以 $\mathrm{MoO}_{3}$ 做为主体, $\mathrm{V}_{2} \mathrm{O}_{5}$ 做为耦合剂研究 $n(\mathrm{~V}) / n(\mathrm{Mo})$ 比对 $\mathrm{V}_{2} \mathrm{O}_{5} / \mathrm{MoO}_{3}$ 复合光催化剂结构和性能的影 响. 我们以聚乙烯吡咯烷酮(PVP)、四水合钿酸铵 $\left.\left(\mathrm{NH}_{4}\right)_{6} \mathrm{Mo}_{7} \mathrm{O}_{24} \cdot 4 \mathrm{H}_{2} \mathrm{O}\right)$ 和偏钒酸铵 $\left(\mathrm{NH}_{4} \mathrm{VO}_{3}\right)$ 为原料, 采用静电纺丝技术结合溶胶 凝胶过程的方法, 成功制备了具有不同 $n(\mathrm{~V}) / n(\mathrm{Mo})$ 比的 $\mathrm{V}_{2} \mathrm{O}_{5} / \mathrm{MoO}_{3}$ 复合光催化剂.

$\mathrm{XRD}$ 结果表明, 当 $n(\mathrm{~V}) / n(\mathrm{Mo})<1 / 6$ 时, 钒离子掺杂进入 $\mathrm{MoO}_{3}$ 晶格内, $n(\mathrm{~V}) / n(\mathrm{Mo})>1 / 6$ 时, 部分钒离子掺杂进入 $\mathrm{MoO}_{3}$ 晶格内, 部分钒离子聚集形成 $\mathrm{V}_{2} \mathrm{O}_{5}$ 晶体, $\mathrm{V}_{2} \mathrm{O}_{5}$ 晶体数量随着 $n(\mathrm{~V}) / n(\mathrm{Mo})$ 逐渐增加, 且尺寸有所增长. 这一点在扫描电镜中得到了进一步的 证实. 扫描电镜结果表明 $\alpha-\mathrm{MoO}_{3}$ 呈规则的层状结构, 为长度约 $3 \mu \mathrm{m}$, 宽度约 $2 \mu \mathrm{m}$, 厚度约 $500 \mathrm{~nm}$ 的表面光滑的正交相 $\mathrm{MoO}_{3}$ 微纳 米片,而 $\mathrm{V}_{2} \mathrm{O}_{5}$ 则为微纳米颗粒, 其中表面光滑的层状 $\mathrm{MoO}_{3}$ 微纳米片散乱分布在块状 $\mathrm{V}_{2} \mathrm{O}_{5}$ 微纳米颗粒之间, 并与 $\mathrm{V}_{2} \mathrm{O}_{5}$ 微纳米颗粒 团簇紧密接触. 由于二者的紧密接触, 可能在二者交界处形成了 $\mathrm{V}_{2} \mathrm{O}_{5} / \mathrm{MoO}_{3}$ 异质结构. 紫外-可见漫反射光谱数据表明, 掺杂或者 异质结构的形成有效降低了 $\mathrm{MoO}_{3}$ 的带隙, 促进了 $\mathrm{MoO}_{3}$ 对可见光的吸收, 拓宽了光响应范围. 为进一步确定 $\mathrm{MoO}_{3}$ 与 $\mathrm{V}_{2} \mathrm{O}_{5}$ 复合前 后元素的化学态变化, 我们进行了XPS能谱测试. 通过对 V 2p和Mo $3 d$ XPS谱图高斯曲线拟合发现, 与纯 $\mathrm{V}_{2} \mathrm{O}_{5}$ 相比, VM-6和VM-2 中不同价态的V元素电子结合能均有所增加. 同时, VM-6和VM-2中的Mo元素的电子结合能与纯 $\mathrm{MoO}_{3}$ 相比有轻微的减少, 这说 明无论是掺杂还是异质结构的形成都使 $\mathrm{V}$ 离子和Mo离子的化学环境有所改变.

我们以亚甲基蓝为探针反应, 测试 $\mathrm{V}_{2} \mathrm{O}_{5} / \mathrm{MoO}_{3}$ 复合光催化剂的催化活性. 结果表明, 无论掺杂还是异质结构的光催化剂光催 化降解亚甲基蓝的活性均远大于纯 $\mathrm{MoO}_{3}$ 和 $\mathrm{V}_{2} \mathrm{O}_{5}$. 这可能是由于 $\mathrm{V} 3 \mathrm{~d}$ 杂质能级的存在以及 $\mathrm{V}_{2} \mathrm{O}_{5}$ 和 $\mathrm{MoO}_{3}$ 交界处异质结构的形成有 效降低了 $\mathrm{MoO}_{3}$ 的带隙, 拓宽了光响应范围. 另一方面, 异质结构有利于光生电子-空穴对的分离, 有效提高了光量子效率. 其中, $n(\mathrm{~V}) / n(\mathrm{Mo})$ 的最佳比为 $1 / 2$, 亚甲基蓝的光降解率高达 $89.23 \%$. 为了测定 $\mathrm{V}_{2} \mathrm{O}_{5} / \mathrm{MoO}_{3}$ 复合光催化剂对邻苯二甲酸二甲酯的光催化 活性, 我们选取了样品纯 $\mathrm{MoO}_{3}, \mathrm{~V}_{2} \mathrm{O}_{5}, \mathrm{VM}-6$ 和VM-2进行测试. 测定结果与光催化降解亚甲基蓝结果吻合, VM-2催化效果最高, 
可达 $82.20 \%$. 并通过高效液相色谱测定邻苯二甲酸二甲酯降解过程的中间产物为邻苯二甲酸.

关键词：静电纺丝法；五氧化二钒；三氧化钿；复合物；光降解活性；邻苯二甲酸二甲酯

收稿日期: 2015-08-26. 接受日期: 2015-10-29. 出版日期: 2015-12-20.

*通讯联系人. 电话: (0431)85717276; 电子信箱: defengzhou65@126.com

\#通讯联系人. 电话: 13820096974; 电子信箱: hwp914@nankai.edu.cn

基金来源：国家自然科学基金(21373120, 21471022); 吉林省科技发展计划项目(20101549, 20130102001JC); 长江学者和创新团

队发展计划资助(PCSIRT13022); 吉林省教育厅项目资助(2013130, 2013146).

本文的英文电子版由Elsevier出版社在ScienceDirect上出版(http://www.sciencedirect.com/science/journal/18722067). 